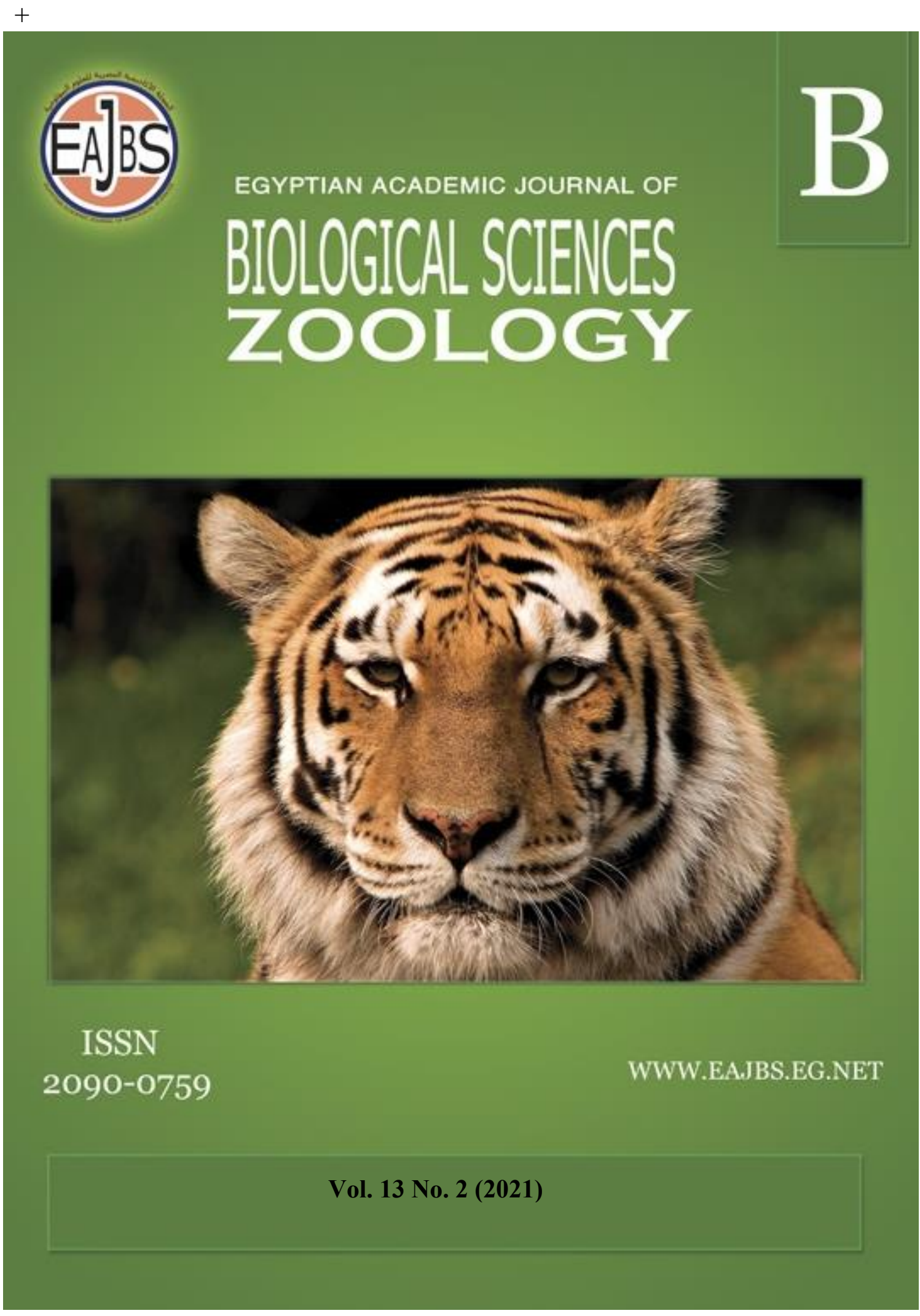

www.eajbs.eg.net 
Egypt. Acad. J. Biolog. Sci., 13(2): 225-244(2021)

Egyptian Academic Journal of Biological Sciences

B. Zoology

ISSN: $2090-0759$

http://eajbsz.journals.ekb.eg/

\title{
Protective Effect of Gallic Acid on Cyclophosphamide-Induced Nephrotoxicity, Oxidative Stress, Genotoxicity, and Histopathological Alterations in Male Albino Rats
}

\author{
Shereen H.B. Elwakeel* , and Amina A.S. Abdel Rahman \\ Zoology Department, Faculty of Women for Arts, Science and Education, Ain Shams \\ University, Asmaa Fahmy Street, Heliopolis, Cairo, Egypt. \\ E.mail*: sherien.elwakeel@women.asu.edu.eg - \\ amina_abdelrahman@,women.asu.edu.eg
}

\begin{abstract}
ARTICLE INFO Article History

Received:1/11/2021

Accepted:3/12/2021

\section{Keywords:}

Cyclophosphamide; nephrotoxicity; Gallic acid; DNAdamage, apoptosis, Zona occluden-1
\end{abstract}

\section{ABSTRACT}

Cyclophosphamide (CP) is a chemotherapeutic agent used to treat various types of cancer. Despite its nervous, hepatic, renal, and cytotoxic side effects, it is a highly effective agent whether used alone or in combination with other chemotherapeutics. This study was designed to examine the prophylactic effects of Gallic acid (GA) on CP-induced acute renal toxicity. Male Wistar albino rats were divided into six groups, 6 animals each: G1 was given normal saline and served as -ve control, while G2 and G3 were given i.p injections of 100 and $200 \mathrm{mg} / \mathrm{kg} \mathrm{GA}$, respectively, for 15 days. G4 was used as a +ve control and received a single i.p. injection of CP $(150 \mathrm{mg} / \mathrm{kg})$. G5 and G6 were treated with the two different doses of GA for 15 days before receiving a single i.p. injection of CP. Animals were euthanized $24 \mathrm{hrs}$ after the last treatment, and their kidneys were carefully dissected out for histological, immunohistochemical investigation of Zona occluden-1(ZO-1), and biochemical examination, as well as the evaluation of P53, apoptotic markers and tumor necrosis factor-alpha (TNF- $\alpha$ ) gene expressions. Blood samples were also taken to determine serum creatinine and urea levels. The intake of GA improved kidney function, as evidenced by lower levels of kidney toxicity markers (urea and creatinine). GA significantly reduced the percent of DNA fragmentation in renal tissue via modulating the levels of glutathione (GSH) and catalase (CAT) enzymes as well as malondialdehyde (MDA). Furthermore, GA reduced renal TNF- $\alpha$ and P53 gene expressions and improved the kidney's histological architecture as well as increasing of ZO-1 immunoexpression. In conclusion, the findings of this study indicate that GA protects against $\mathrm{CP}$-induced renal toxicity via an anti-inflammatory and antioxidant mechanism. We believe that GA may have prophylactic effects against $\mathrm{CP}$-induced nephrotoxicity.

\section{INTRODUCTION}

Cyclophosphamide (CP) is an active alkylating cytostatic and an immunosuppressive mediator that is applied in chemotherapy for Hodgkin's and non- 
Hodgkin's lymphoma, rheumatoid arthritis, leukemia, neuroblastoma, lupus erythematosus, Burkitt's lymphoma, multiple myeloma, multiple sclerosis, breast, lung cancer, and in organ transplantation (Hamsa \& Kuttan, 2012 and Rehman et al., 2012). Furthermore, CP is metabolized to several compounds in the liver by microsomal cytochrome P450 (Ayala et al., 2014). The active metabolite 4hydroxycyclophosphamide is stable in the presence of the cyclic tautomer aldophosphamide. These two compounds are circulated to tumor cells, where aldophosphamide cleaves to produce active phosphoramide mustard and acrolein. (Tripathi \& Jena, 2009). Moreover, phosphoramide is responsible for anti-tumor effects as it binds to DNA forming an adduct that breaks cross-linking purine bases in DNA, inhibiting protein synthesis as well as the death of tumor dividing cells, while acrolein induces urotoxicity, nephrotoxicity, and hemorrhagic cystitis (Osawa et al., 2011).

Unfortunately, the major problems in cancer treatment are the resistance of the cancer cells to chemotherapeutic drugs (Alfarouk et al., 2015, Rueff \& Rodrigues, 2016). Therefore, the alternative treatments allow the combination of cytotoxic agents with chemotherapeutic drugs to reduce the concentrations of the drugs, enhancing the treatment efficacy and decreasing their side effects (Hedigan, 2010). Herein, plants can utilize aromatic substances, such as phenolic acids and flavonoids that exhibit antioxidant properties due to their metal-chelating and hydrogen-donating capacities, thus allowing to decrease the occurrence of oxidative stress-related diseases (Rao et al., 2010 \& Engwa, 2018).In addition, phenolic agents can also link with iron and copper metal ions that can cause radical creation through the Fenton reaction and prevent this reaction (Kilic et al., 2019). Among the phenolic compounds, Gallic acid (GA) (3, 4, 5trihydroxy benzoic acid) is synthesized naturally from many plants such as red wine and grapes (Hornedo-Ortega et al., 2020), green tea (Can Agca et al., 2020), oak bark (Dróżdż \& Pyrzynska, 2018), witch hazel (Wang et al., 2003), sumac (Fereidoonfar et al., 2019), nut, apple peels, gallnuts, tea leaves, bananas, areca, lemon, strawberries, pineapples, different berries, mango, and other fruits (Safaei et al., 2018 and Ola Davies et al., 2018). GA is composed of three hydroxyl groups attached to the aromatic ring in an ortho position (Fig.1) forming the strongest ROS scavenging activity of phenolic acid as well as antioxidant effect (Borde et al., 2011 \& Locatelli et al., 2013).

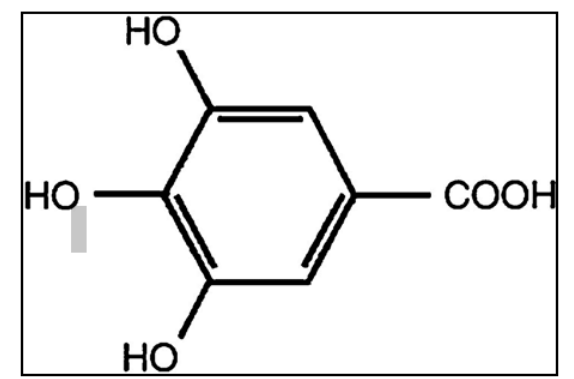

Fig. 1: Chemical structure of Gallic acid (3,4,5 - trihydroxybenzoic acid) (Reckziegel et al., 2016).

Furthermore, other important characteristics of GA include anti-viral (TrujilloCorrea et al., 2019), anti-bacterial (Rajamanickam et al., 2019), anti-hyperglycemic (Variya et al., 2020), anti-inflammatory (Asci et al., 2017\&Bustami et al., 2018), and anti-cancer agent (Zhang et al., 2019 \& Khorsandi et al., 2020).

Thus, due to the deleterious effects and nephrotoxic side effects of CP and the benefits of GA as a safe and cheap dietary compound that contains phytochemicals and has protective efficacy against CP-induced nephrotoxicity. The present study was 
The Protective Effect of Gallic Acid on Cyclophosphamide-Induced Nephrotoxicity, Oxidative Stress, Genotoxicity, and Histopathological Alterations in Male Albino Rats.

designated to help in finding a protective therapeutic approach to prevent the destructive effect of oxidative stress induced by $\mathrm{CP}$ and it may be beneficial for patients who have been using $\mathrm{CP}$ for a long time.

\section{MATERIALS AND METHODS}

\section{Drugs and Chemicals:}

Cyclophosphamide (Endoxan - Sigma-Aldrich Chemical Co. St. Louis, Missouri, USA) was dissolved in sterile water and freshly prepared immediately before each intraperitoneal injection.

Gallic acid (purity: 99.5\%) extra pure was obtained from Sigma Aldrich Company (USA). All chemicals and reagents used during the experiment met the highest purity grade value according to international standards.

\section{Animals:}

Thirty-six adult male Wister albino rats, weighing (170- 200 g), aged 7-9 weeks old were used in this study. Animals were obtained from the Animal House Colony, National Research Centre, and Cairo, Egypt. The males were chosen according to an earlier study which found that the clastogenic effects of $\mathrm{CP}$ were more prominent in males than females (Krishna et al., 1991). The animals were housed in stainless steel cages, 6 rats per cage, in a temperature-controlled environment $\left(22 \pm 2^{\circ} \mathrm{C}\right)$ with a 12 -h light/dark cycle and humidity levels ranging from 50\% to $70 \%$. Animals were acclimatized for 2 weeks before beginning the experiment. They were fed by standard rat pellet diet and tap water Ad libitum during the study. All animal studies are strictly conformed to the animal experiment guidelines of the Committee on Care and Use of Experimental Animal Resources, Medical Research Center, Ain Shams University.

\section{Experimental Protocol:}

Two weeks after acclimatization, rats were randomly divided into six experimental groups as follow: -

- Group 1 (negative control): received $1 \mathrm{ml} / \mathrm{kg} / \mathrm{day} 0.9 \% \mathrm{NaCl}$ intraperitoneally (i.p) for 15 days.

- Group 2 and Group 3: received i.p. injections of 100\&200 mg/kg GA respectively, for 15 days. GA doses were selected according to Ahmadvand et al. (2019) and Manshare et al. (2018).

- Group 4: (positive control) animals received single i.p. injection of $150 \mathrm{mg} / \mathrm{kg} \mathrm{CP}$ to induce nephrotoxicity (150 ml /kg/i.p/single injection) (Abraham et al., 2009).

- Group 5: animals were injected with the low dose of GA (100mg $/ \mathrm{kg})$ for 15 days before receiving a single dose of CP $(150 \mathrm{mg} / \mathrm{kg} / \mathrm{i} . \mathrm{p})$.

- Group 6: animals were treated with a high dose of GA (200 mg/kg) for 15 days then received a single i.p injection of $\mathrm{CP}(150 \mathrm{mg} / \mathrm{kg} / \mathrm{i} . \mathrm{p})$.

All animals are monitored daily for health conditions during the treatment period. After the last treatment, rats were sacrificed under ether anesthesia and blood was collected directly by a cardiac puncture from the heart of each animal, allowed to clot for at least $30 \mathrm{~min}$ at room temperature. The blood was centrifuged at $3000 \times g$ for 10 minutes to obtain clear sera, which were then stored at $-70^{\circ} \mathrm{C}$ to assess kidney functions. In addition, kidneys were rapidly dissected out, washed in ice-cold isotonic saline, blotted between two filter papers, and used in the investigations described below.

\section{Biochemical Parameters:}

Antioxidant Enzymes and Lipid Peroxidation Marker Assays:The left kidney from each animal was homogenized in chilled $(10 \mathrm{mM})$ phosphate-buffered saline (PBS) with 
optimal $\mathrm{pH} 7.4$, centrifuged, and a part of the supernatant was used for evaluating the following:

- Malondialdehyde (MDA): the final product of lipid peroxidation using the thiobarbituric acid (TBA) test (Pedeson et al., 1990).

- Catalase (CAT) Activity by assessing the decomposition of $\mathrm{H}_{2} \mathrm{O}_{2}$ at $240 \mathrm{~nm}$ as stated by Aebi (1983).

- Measurement of renal Glutathione levels (GSH): GSH content in the renal tissue was measured spectrophotometrically according to Ellman's method (Ellman, 1959).

\section{Determination of Kidney Functions:}

Urea and creatinine levels in serum were determined using commercially available kits (Todd et al., 1974).

DNA Fragmentation (DNAF) Assay:

Genomic DNA was extracted from the renal tissue using the Wizard® Genomic DNA Purification kit (Promega Corporation, Madison, WI, USA) according to the manufacturer's instructions. To assess endonuclease-dependent ladder-like DNA fragmentation by gel electrophoresis, DNA was loaded onto agarose gel (15 $\mu \mathrm{g} / \mathrm{lane})$. DNA laddering was determined by electrophoresis on a $2 \%$ agarose gel containing $0.5 \mu \mathrm{g} / \mathrm{ml}$ ethidium bromide. DNA ladder (Jena Bioscience, USA) was used and served as a DNA base pair marker (Matassov, et al., 2004). After electrophoresis, gels were visualized by the Gel Documentation system (Biometra, Germany). Furthermore, the percentages of fragmented DNA in renal tissue were assessed by the method described by Boraschi and Maurizi (1998).

\section{Quantitative RT-PCR Analysis:}

Total RNA was extracted from renal tissue homogenate using the RNA Purification Kit (Qiagen, Valencia, CA) according to the manufacturer's instruction. Then, cDNA was synthesized using the SuperScript cDNA synthesis Kit (Thermo Fisher, Scientific) according to the manufacturer's instruction, and quantitative real-time PCR (qPCR) was performed using SYBR Green Master Mix PCR Kit (Qiagen, Valencia, CA) on an ABI Prism 7500 Thermal Cycler (Applied Biosystems step one plus, Foster City, California, USA). The qPCR experiment was carried out after the manufacturer's instructions.PCR primers for candidate genes (Bax, Bcl 2 , caspase-3, P53, and TNF- $\alpha$ ) and house-keeping gene ( $\beta$-actin) were purchased from Applied Biosystems (Table 1). The thermal cycling conditions and calculation of relative expression using $2^{-\Delta \Delta \mathrm{Ct}}$ were done as previously described by (Livak and Schmittgen, 2001).

Table 1: Sequence of the primers used for real-time PCR.

\begin{tabular}{|l|l|}
\hline \multicolumn{2}{|l|}{ BAX (Bcl-2 -associated X protein) } \\
\hline Forward primer & 5'-GTT TCA TCC AGG ATC GAG CAG-3' \\
\hline Reverse primer & 5'-CAT CTT CTT CCA GAT GGT GA-3' \\
\hline Bcl-2(B-cell lymphoma protein 2) \\
\hline Forward primer & 5'-CCT GTG GAT GAC TGA GTA CC-3' \\
\hline Reverse primer & 5'-GAG ACA GCC AGG AGA AAT CA-3' \\
\hline Caspase-3 \\
\hline Forward primer & 5'- GGAAGCGAATCAATGGACTCTGG -3' \\
\hline Reverse primer & 5'- GCATCGACATCTGTACCAGACC -3' \\
\hline P53 & \\
\hline Forward primer & 5'-CCTCAGCATCTTATCCGAGTGG-3' \\
\hline Reverse primer & 5'- TGGATGGTGGTACAGTCAGAGC-3' \\
\hline TNF- $\boldsymbol{\alpha}$ & \\
\hline Forward primer & 5'-CTCTTCTGCCTGCTGCACTTTG-3' \\
\hline Reverse primer & 5'- ATGGGCTACAGGCTTGTCACTC-3' \\
\hline Beta-actin (housekeeping gene) \\
\hline Forward primer & 5'- TCT GGC ACC ACA CCT TCT ACA ATG -3' \\
\hline Reverse primer & $5^{\prime}$ - AGC ACA GCC TGG ATA GCA ACG -3' \\
\hline
\end{tabular}


The Protective Effect of Gallic Acid on Cyclophosphamide-Induced Nephrotoxicity, Oxidative Stress, Genotoxicity, and Histopathological Alterations in Male Albino Rats.

\section{Histopathological Examination of the Kidney:}

Renal tissue samples were flushed and fixed in $10 \%$ neutral buffered formalin for 72 hrs. Samples were trimmed and processed in serial grades of ethanols, cleared in xylene, infiltrated, and embedded into Paraplast tissue embedding media. $4 \mu \mathrm{m}$ thick tissue sections were cut by rotatory microtome, mounted on a glass slide, and stained by Hematoxylin and Eosin as a general morphological staining method according to Culling (2013).

\section{Immunohistochemical Examination:}

5 microns thick paraffin-embedded tissue sections were immunohistochemically prepared according to the manufacturer's protocol. Deparaffinized retrieved tissue sections were treated with $0.3 \% \mathrm{H}_{2} \mathrm{O}_{2}$ for 20 minutes for blocking the endogenous peroxidase activity, incubated with Anti-ZO 1(1:1000 - Abcam - EPR19945-224) overnight at $4{ }^{\circ} \mathrm{C}$. Tissue sections were washed with PBS before incubating with the secondary antibody HRP Envision kit (DAKO) for 20 minutes. Then, slides were washed and incubated with diaminobenzidine (DAB) for 15 mins. Washed again by PBS, counterstained with haematoxylin, dehydrated, and cleared in xylene before being covered for microscopic examination. The specificity of the technique was assessed by negative controls.

\section{Histological Analysis:}

6 non-overlapping fields were randomly selected and scanned from each sample to determine the optical density of immuno-expression levels of ZO-1 in immuno-stained sections.

All microscopic examinations and data were obtained by using the Leica Application module for histological analysis attached to the Full HD microscopic imaging system (Leica Microsystems GmbH, Germany).

\section{Statistical Analysis:}

Results were presented as means \pm standard error (S.E.M.). Statistical comparisons between different groups were done using one-way analysis of variance (ANOVA) followed by the Tukey HSD multiple comparison test. Significance was accepted at P $\leq$ 0.05 .

\section{RESULTS}

No mortality was detected in any of the experimental animal groups during the study period. The treatment with saline and GA for 2 weeks did not display statistical differences in any of the measured parameters when compared with the control group except for CAT enzymes, which increased significantly $(\mathrm{P}<0.01)$ with the GA treatment.

\section{Biochemical Analysis:}

\section{Effect of GA on Oxidative Stress And Antioxidant Enzymes Levels In Rats' Kidneys Treated With CP.:}

MDA levels in the kidney of the CP-treated group were significantly elevated $(\mathrm{P}<0.01)$ when compared to the control group and GA protective groups. (Table 2). Meanwhile giving the animals two prophylactic doses of GA $(100 \mathrm{mg} / \mathrm{kg}$ or $200 \mathrm{mg} / \mathrm{kg})$ before administrating $\mathrm{CP}$-dose significantly $(\mathrm{P}<0.01)$ decreased MDA levels compared to those that received $\mathrm{CP}$-alone. In contrast, both $\mathrm{CAT}$ and $\mathrm{GSH}$ enzymes in the kidney of $\mathrm{CP}$-treated groups were significantly $(\mathrm{P}<0.01)$ reduced $(70.27 \pm 2.41$ and $51.83 \pm 1.90$ respectively) as compared with the control group (136.13 \pm 1.62 and112.5 \pm 1.21 respectively) (Table 2). The reduction in the level of renal tissue contents of antioxidant enzymes (CAT and GSH) was elevated in GA protective groups. 


\section{Serum Levels of Renal Marker}

The CP-treated group showed significantly $(\mathrm{P}<0.01)$ high serum levels of renal urea and creatinine when compared to the control group. GA administration for 15 days before CP injection significantly lowered serum levels of urea and creatinine in a dosedependent manner when compared with the CP-treated group (Table 2).

Table 2: The effect of Gallic acid on lipid peroxidation (MDA), antioxidants enzymes, renal marker levels and DNAF in kidney tissues in adult male albino rats.

\begin{tabular}{|c|c|c|c|c|c|c|}
\hline $\begin{array}{l}\text { Parameter } \\
\text { Treatment } \\
\end{array}$ & $\begin{array}{l}\text { MDA level } \\
\text { (nmol/gm) }\end{array}$ & $\begin{array}{c}\text { CAT enzyme } \\
(\mathrm{u} / \mathrm{gm})\end{array}$ & $\begin{array}{c}\text { GSH level } \\
(\mathrm{mmol} / \mathrm{gm})\end{array}$ & $\begin{array}{c}\text { Urea level } \\
\text { (mg/dl) }\end{array}$ & $\begin{array}{c}\text { creatinine level } \\
(\mathrm{mg} / \mathrm{dl})\end{array}$ & DNAF \\
\hline Control & $13.05 \pm 0.93$ & $136.13 \pm 1.62$ & $112.5 \pm 1.21$ & $19.93 \pm 0.18$ & $1.30 \pm 0.11$ & $\pm 0.07 \# 1.97$ \\
\hline GA $(100 \mathrm{mg} / \mathrm{kg})$ & $13.05 \pm 0.43^{\text {ns \# }}$ & $141.18 \pm 2.87^{* * \#}$ & $116.2 \pm 0.99 \mathrm{~ns} \#$ & $19.65 \pm 0.36^{\text {ns }}$ & $1.13 \pm 0.02^{\mathrm{ns} \#}$ & \pm 0.09 ns\# 1.43 \\
\hline GA $(200 \mathrm{mg} / \mathrm{kg})$ & $13.93 \pm 0.27$ ns & $138.08 \pm 3.09^{* * \# \#}$ & $115.86 \pm 1.17$ ns & $19.16 \pm 0.45$ ns\# & $1.31 \pm 0.09^{\mathrm{ns} \#}$ & \pm 0.1 ns\# 1.54 \\
\hline CP-treated group & $60.75 \pm 3.15^{* *}$ & $70.27 \pm 2.41^{* *}$ & $51.83 \pm 1.90^{* *}$ & $49.7 \pm 1.45^{* *}$ & $5.28 \pm 0.18^{* *}$ & $\pm 0.76^{* *} 13.11$ \\
\hline $\mathrm{GA}(100 \mathrm{mg} / \mathrm{kg})+\mathrm{CP}$ & $23.93 \pm 1.01^{* * \# \#}$ & $119.95 \pm 2.90^{* * \#}$ & $94.51 \pm 2.56^{* * \#}$ & $25.76 \pm 0.38^{* * \#}$ & $2.26 \pm 0.12^{* * \# \#}$ & \pm 0.09 ns 2.016 \\
\hline GA $(200 \mathrm{mg} / \mathrm{kg})+\mathrm{CP}$ & $16.88 \pm 0.99^{\mathrm{ns} \#}$ & $126.58 \pm 2.78^{\mathrm{ns} \#}$ & $104.11 \pm 3.86^{\text {nsw }}$ & $22.99 \pm 0.21 * \#$ & $1.88 \pm 0.13^{* * \#}$ & $\pm 0.088^{\mathrm{n}} 1.41$ \\
\hline
\end{tabular}

All the values are presented as the mean $\pm \operatorname{SEM}(n=6)$. ${ }^{n s} P>0.05$ compared with the control group. ${ }^{*} \mathrm{P}<0.05$ compared with the control group.

${ }^{\#} \mathbf{P}<0.01$ compared with the $\mathbf{C P}$-treated group.

${ }^{* *} \mathbf{P}<0.01$ compared with the control group.

\section{Genotoxicity Studies:}

\section{DNA Fragmentation in Kidney Cells:}

DNA injuries in kidney cells were evaluated as a DNA ladder representing a series of fragments using agarose gel electrophoresis assay (Fig. 2a) and colorimetrically as the percentages of fragmented DNA utilizing the diphenylamine (DPA) assay (Fig. 2b). The results indicate that the treatment with CP induced DNA damage in the kidney cells. The percentage of fragmented DNA in the kidney cells of rats treated with CP was found to be 6.6 times higher than in the control group. Meanwhile, treatment with the two doses of GA significantly $(\mathrm{P}<0.01)$ decreased the percentages of fragmented DNA in a dose-dependent manner as compared with the CP-treated group.
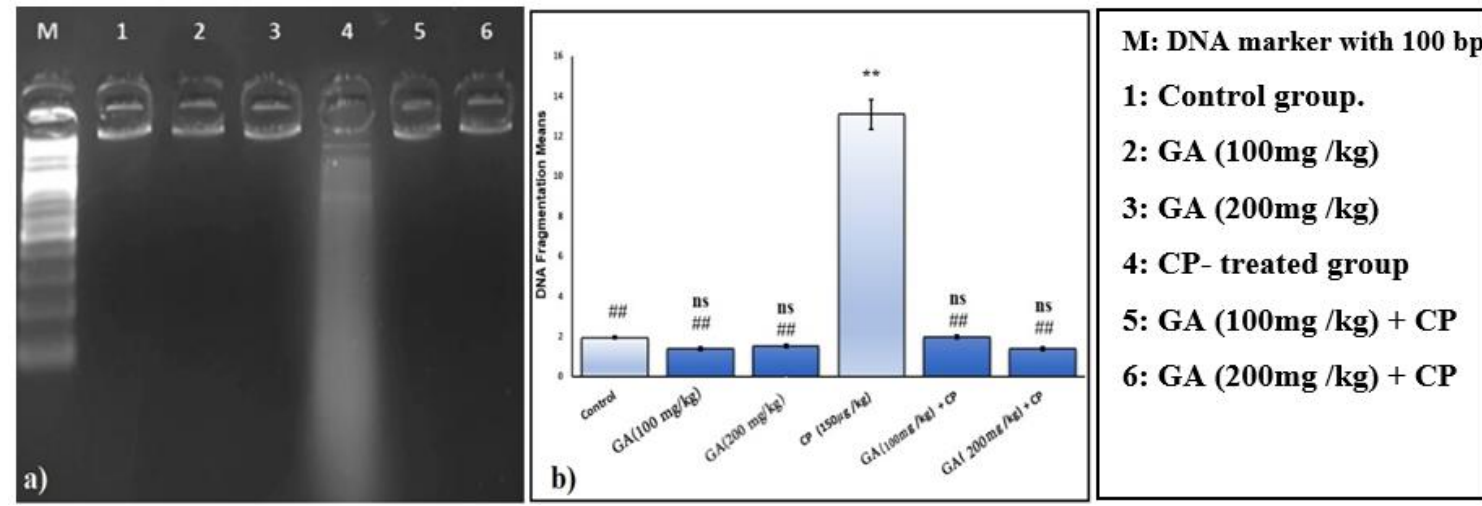

Fig. 2: The prophylactic effect of GA on the renal cellular DNA of rats treated with CP. a) An agarose gel electrophoresis shows DNA fragmentation. Lane1, 2, 3, 5, 6: DNA without streaks or laddering. Lane 4: DNA with marked streaks and laddering.

b) mean percentages of fragmented DNA in different groups using DPA assay.

All the values are presented as the mean $\pm \operatorname{SEM}(\mathrm{n}=6)$.

${ }^{n} \mathrm{P}>0.05$ compared with the control group. ${ }^{* *} \mathrm{P}<0.01$ compared with the control group. ${ }^{\# \#} \mathrm{P}<0.01$ compared with the CP- treated group.

As shown in Fig. 3, the mRNA level of TNF- $\alpha$, Caspase-3, P53, and Bax were significantly $(\mathrm{P}<0.01)$ increased in the $\mathrm{CP}$-treated group when compared to the normal control group. The mRNA levels of the rear genes in the GA control groups were nearly identical to the control group. Similarly, GA administration before CP-intoxication 
The Protective Effect of Gallic Acid on Cyclophosphamide-Induced Nephrotoxicity, Oxidative Stress, Genotoxicity, and Histopathological Alterations in Male Albino Rats.

revealed a significant $(\mathrm{P}<0.01)$ improvement in these gene expressions. In contrast, Bcl2 expression in the kidney of the $\mathrm{CP}$-treated group was significantly $(\mathrm{P}<0.01)$ decreased as compared to the control group. While pre-treatment with GA significantly $(\mathrm{P}<0.01)$ increased the levels of Bcl-2 as compared to the CP-treated group (Fig. 3e).

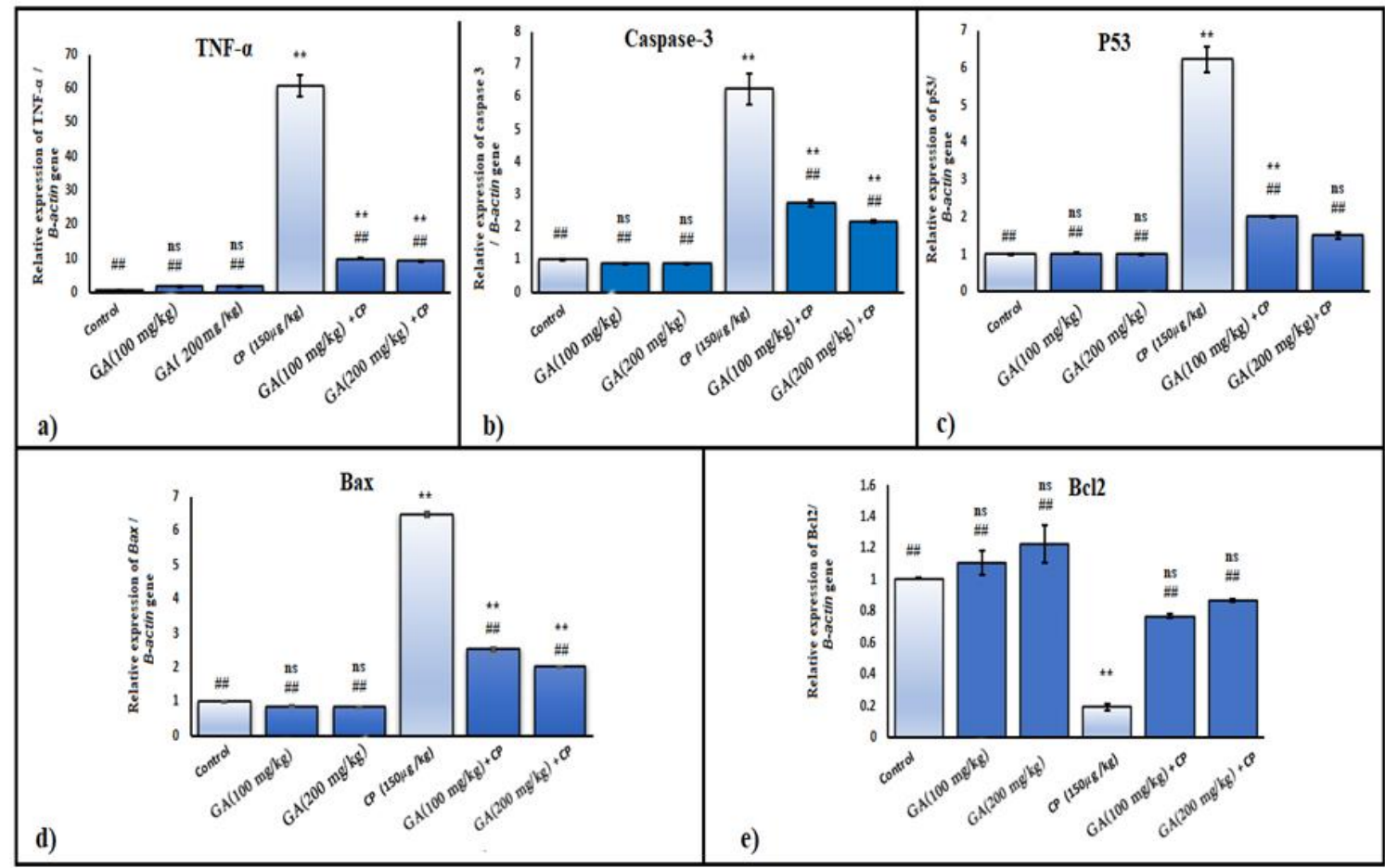

Fig. 3: Comparison between the TNF- $\alpha$, Caspase-3, P53, Bax, and BCL-2 gene expressions in rat kidney tissue of the studied groups. Values represented as mean \pm standard error mean.

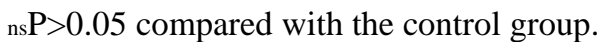

**P $<0.01$ compared with the control group.

$\# \mathrm{P}<0.01$ compared with the $\mathrm{CP}$ - treated group

\section{Histological Investigation:}

In the present investigation, the histological examinations mostly supported the results of serum enzymes and oxidative stress profiles. In H\&E-stained sections, the control group and the two GA control groups $(100 \& 200 \mathrm{mg} / \mathrm{kg})$ showed normal and wellorganized histological features of renal parenchyma with many apparent intact renal corpuscles (black star) and segments of nephron with intact tubular epithelium (arrow) with intact interstitial tissue as well as vasculatures as shown in Fig. 4 (A, B\& C) respectively.

On the other hand, the rats injected with $\mathrm{CP}$ showed a moderate tubular dilatation of cortical tubular segments (red star) with moderate figures of tubular epithelium necrotic changes (dashed arrow), loss of luminal border integrity and periglomerular lymphocytic infiltrates (red arrow) as well as mild congested interstitial BVs. with a certain degree of tubular degeneration, and tubular necrosis, (Fig.4D).

However, kidney sections of treated rats with either of the two doses of GA pro tected the renal glomeruli and tubules from the deleterious effect of the CP induction in a dose-dependent manner. The kidney sections showed a significant improvement in the morphological features of renal parenchyma with minor sporadic records of tubular dilatation, focal necrotic and degenerative changes of the tubular epithelium (red arrow) as well as mild congested glomerular tufts (star) and minimal inflammatory cells 
infiltrates compared to the rats treated with $\mathrm{CP}$ alone. Moreover, the high dose of GA restored the architecture of glomerulus tuft and renal tubules which appeared nearly similar to the control groups (Fig.4E \&F).
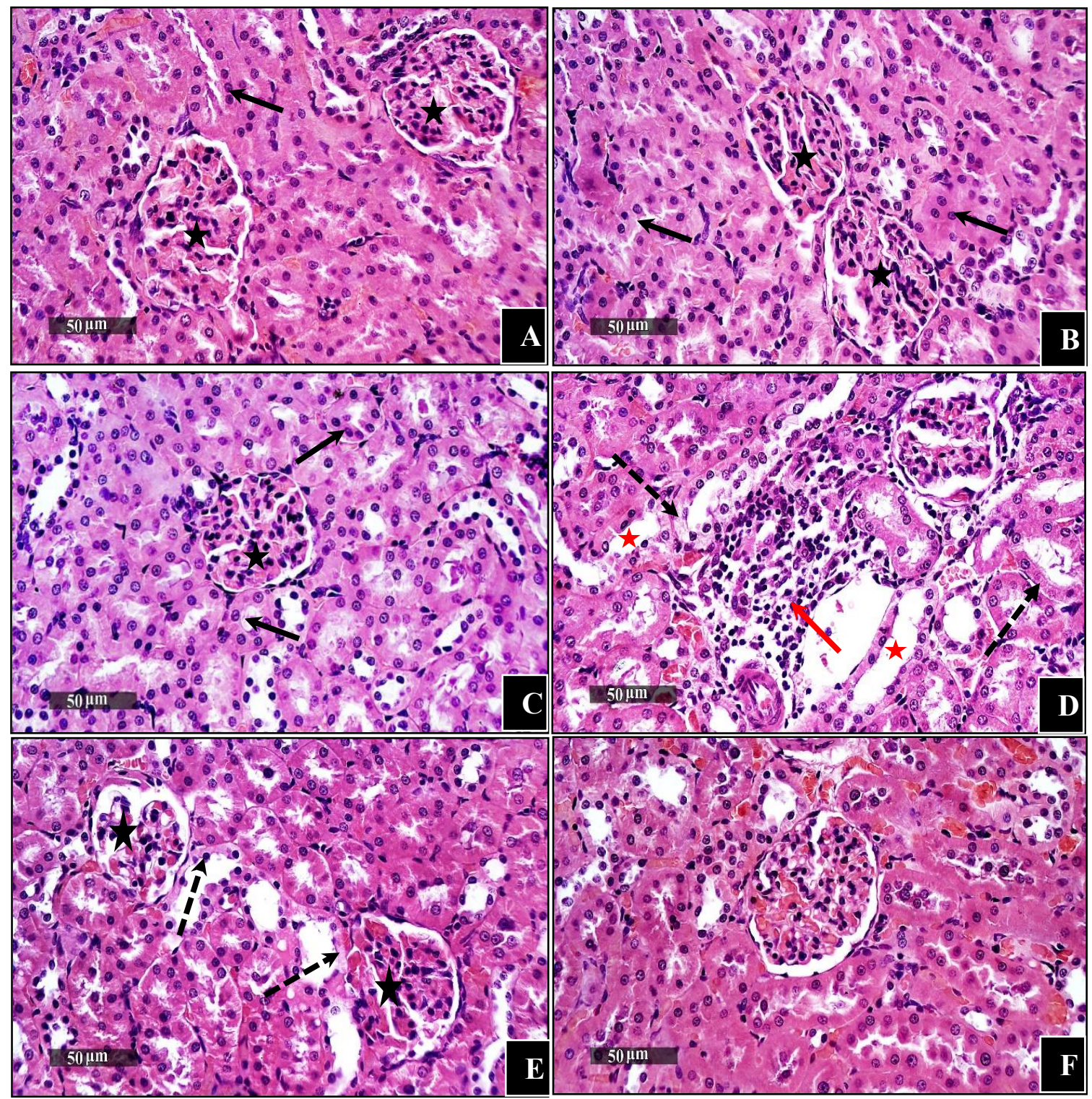

Fig (4): Photomicrographs of Hematoxylin and Eosin-stained kidney sections showing the protective effect of two doses of $\mathbf{G A}$ on CP-induced changes in the kidney of adult male rats. (A): Control group, kidney show normal architecture with normal glomeruli (black star) and intact tubular epithelium (arrow). (B): GA (100mg / $\mathbf{k g}$ ), shows normal architecture with normal glomeruli (black star) and intact tubular epithelium (arrow). (C): GA (200 $\mathbf{~ m g ~ / ~} \mathbf{k g})$. (D): CP-treated group, shows renal tubular dilatation (red star), moderate tubular epithelium necrotic changes (dashed arrow), and periglomerular lymphocytic infiltrates (red arrow). (E): GA $(\mathbf{1 0 0 m g} / \mathbf{k g})+\mathbf{C P}$, shows nearly normal morphological features of renal parenchyma with minor tubular dilatation, focal necrotic and degenerative changes of tubular epithelium (red arrow), mild congested glomerular tufts (star). (F): GA $(200 \mathbf{~ m g} / \mathbf{k g})+\mathbf{C P}$, shows normal features of glomerulus tuft and renal tubules architecture. (H\& E, X 400). 
The Protective Effect of Gallic Acid on Cyclophosphamide-Induced Nephrotoxicity, Oxidative Stress, Genotoxicity, and Histopathological Alterations in Male Albino Rats.

\section{Immunohistochemical Investigation (IHC):}

Along side the histological investigation, optical density expression of the tightjunction proteins, ZO-1was detected in the glomeruli histologically by IHC staining (Fig.5). The means and standard error are used to represent the values (Fig. 5G). There was no significant $(\mathrm{P}>0.05)$ correlation detected between the control group and either of the GA-treated groups (Fig. 5A, B \& C). In contrast, there was a significant reduction of ZO-1protein expression after $\mathrm{CP}$ administration $(\mathrm{P}<0.01)$ as compared to the control group(Fig. 5D). However, the treatment with the two doses of GA protected the tight junction between the cells from the $\mathrm{CP}$ effect by inducing a significant $(\mathrm{P}<0.01)$ elevation of ZO-1 expression in a dose-dependent manner when compared with the CPtreated group as shown in Fig.5 (E\& F).

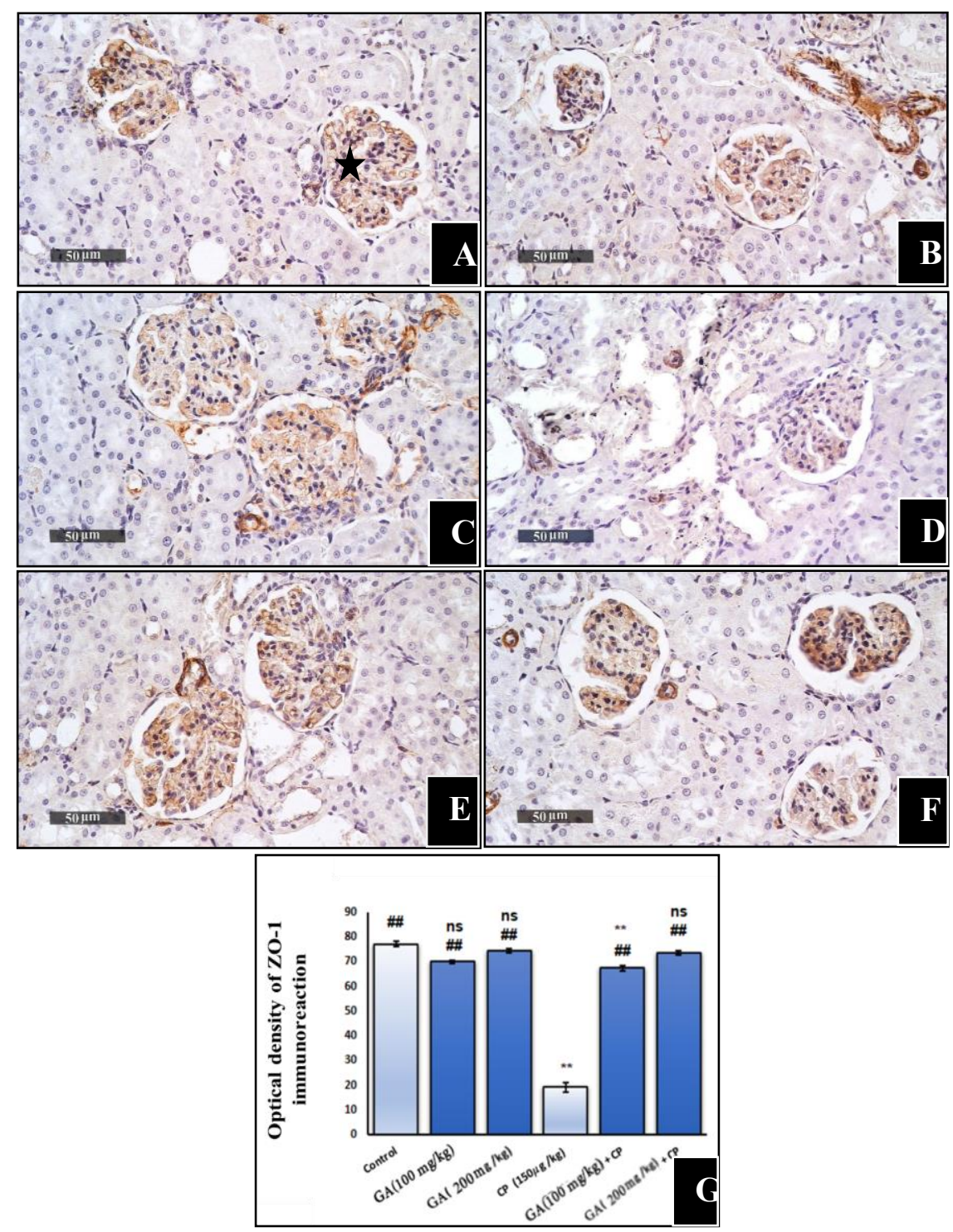

Fig. 5: Photomicrographs of ZO-1 Immunohistochemistry in kidney tissues. (A): Control group, show normal ZO-1 optical density immuno-reaction with intact brown colour (star). (B):GA (100 mg /kg) group, shows normal distribution of immuno-reactive cells. (C): GA (200 $\mathbf{~ m g ~} / \mathbf{k g})$ group, show normal distribution of immuno-reactive cells. (D): CP- treated group, show reduction of ZO-1 immuno-reactive cells. (E): GA (100 $\mathbf{~ m g ~ / ~} \mathbf{k g})+\mathbf{C P}$, show increase of ZO-1 immuno-reactive cells. (F): GA (200 $\mathbf{~ m g ~} / \mathbf{k g})$ + CP, show marked increase of ZO-1 immuno-reactive cells. (G): Chart illustrates the optical density of ZO-1 immunoreaction in kidney tissues of all groups. The values are represented as mean \pm S.E and significance $(\mathrm{p}<0.05)$ compared to the control group; ${ }^{\mathrm{ns}} \mathbf{P}>\mathbf{0 . 0 5}$ compared with the control group. ${ }^{* *} \mathbf{P}<\mathbf{0 . 0 1}$ compared with the control group. ${ }^{\# \#} \mathbf{P}<\mathbf{0 . 0 1}$ compared with the CP- treated group. 


\section{DISCUSSION}

Cyclophosphamide is a highly effective chemotherapeutic agent used alone or in combination with other chemotherapeutics to treat various types of cancer, which causes tissue toxicity by its reactive metabolites. However, the results of the present study reported that a single dose of $\mathrm{CP}$ induced kidney damage as evidenced by increased renal function biomarkers, i.e., serum urea and creatinine. These results agreed with (Olayinka et al., 2015; Bokolo and Adikwu, 2018; Ayza et al., 2020 and Aladaileh et al., 2021) who reported a significant increase in plasma levels of urea and creatinine after intraperitoneal injection of $\mathrm{CP}$ to rats, indicating marked damage to functioning nephrons.

Oxidative stress and free radical generation in renal tubular cells have been proposed to be the reason for CP-induced renal damage (Abraham et al., 2007 \&AlSaeed et al., 2017). In the present study, GA ameliorated CP-induced renal toxicity as indicated by the decrease of serum urea and creatinine levels by maintaining the renal cellular membrane integrity through improving the antioxidant status (Ahmadvand et al., 2019). It seems that GA had a positive effect on renal function. Similar studies showed that administration of GA for seven or eight consecutive days in doses of 30, 200, or 400 $\mathrm{mg} / \mathrm{kg}$ could improve kidney dysfunction in rats intoxicated with gentamicin, through its antioxidant activities and its capacity to keep the cellular membrane integrity (Ghaznavi et al., 2018).

Also, previous studies indicated that GA succeed to protect the kidney in pathological conditions such as lindane-induced toxicity (Said, 2011\&Manshare et al., 2018) and Renal ischemia-reperfusion injury (RIR) (Ahmadvand et al., 2019) due to its anti-oxidative properties. The results offered by a previous study expressed that GA, 20 $\mathrm{mg} / \mathrm{kg}$ for seven days isolated from Peltiphyllum peltatum attenuated the serum levels of urea, creatinine, and uric acid in rats treated with sodium fluoride $(\mathrm{NaF})$ induced nephrotoxicity (Nabavi et al., 2013).

In the current study, we observed that intraperitoneal administration of $\mathrm{CP}$ led to oxidative stress as evident from significant increases in MDA level and decreases in antioxidant enzymes such as GSH and CAT. MDA is one of the final products of lipid peroxidation. Lipid peroxidation causes the break of lipids with the formation of reactive compounds leading to DNA and protein oxidation, changes in the permeability of lipid bilayer membrane, and can dramatically alter cell integrity (Barrera, 2012). In the same manner, CP exhibited an increase in MDA level induce kidney injury as stated by Aladaileh et al. (2021).

Furthermore, increased serum levels of MDA can be the cause of many diseases associated with oxidative stress, such as diabetes (Kumari et al., 2008). In the present study, animals pre-treated with GA displayed a significant decrease in MDA level especially with the highest dose of GA. Consistent with our findings, several reports highlighted that natural antioxidants such as Gallic and tannic Acids Akomolafe et al. (2014), eugenol, selenium, hydroxytyrosol, quercetin (Chashmi et al., 2017), erdosteine, $\alpha$-tocopherol (Yurdakul et al., 2010) provoked the ameliorative effects on MDA levels. The restoration of oxidative stress by improving the antioxidant defense system might be ascribed to the free radical scavenging/antioxidant properties of the phytochemical constituents present in GA. These compounds can decrease lipid peroxidation and attenuate renal dysfunction and increase antioxidant enzyme activity. (Balagangadharan, 2012; Chilwant and Muglikar, 2012 and Aladaileh et al., 2021).

Additionally, in the current study, the GSH and CAT activities were significantly decreased in CP-treated rats as reported earlier by Olayinka et al. (2015), this could be 
due to the inactivation of cellular antioxidants by the ROS and oxidative stress with a cascade of effects on the functional and structural integrity of organelles and cell membranes (Nagaraj et al., 2012).

Consistency with the results of this study, other researchers indicated that toxicity of $\mathrm{CP}$ is due to depletion of the GSH concentration and decreased antioxidant enzyme activity in renal tissue of rats (Said et al., 2015\&Aladaileh et al., 2021). The CP-induced depletion of GSH is primarily mediated by the interaction of its reactive metabolite; acrolein with cysteine which is one of the constituent amino acids of GSH (HamsaandKuttan, 2012). Therefore, some sulfhydryl (SH) compounds and cysteine itself have been observed to protect the animal from the toxic effect of CP (Rehman et al., 2012).

According to the findings of the current study, GA improved antioxidant status by increasing GSH levels. Our findings are consistent with those of Olayinka et al. (2016), Ghaznavi et al. (2018), and Bahrami et al. (2021) who hypothesized that GA and other natural antioxidants could reduce lipid peroxidation and nitric oxide while increasing GSH content. Increased NO levels cause tissue damage primarily through the reaction with superoxide anion and the production of peroxynitrite, a powerful oxidant.

The increased CAT and GSH activities observed in GA-treated animals may be related to GA's ability to scavenge ROS and elevate levels of antioxidant enzymes' gene expression (Ghaznavi et al., 2018).

Moreover, different studies showed that GA could augment the activities of antioxidant enzymes SOD, CAT, and GSH in many pathological conditions such as myocardial infarction, CCl4-induced chronic liver injury, diabetes, and spinal cord injury (Oboh et al., 2016 \& Kahkeshani et al., 2019). According to previous studies, GA has a huge antioxidant capacity that normalized the abnormal outcomes.

Also, the present study revealed that a single intraperitoneal administration of $\mathrm{CP}$ in rats induced a significant increase in both DNA strand breaks and a percent of DNA fragmentation in renal tissue that could be a result of excessive oxidative stress induced by CP injection (Rehman et al., 2012).

The current study found that pre-treatment with GA at both doses resulted in a significant reduction in the percent of DNA fragmentation. The current findings point to GA playing an important role in preventing CP-induced DNA damage and genotoxicity.

Moreover, increased ROS production by $\mathrm{CP}$ in renal tissues can damage several cell structures (Amien et al., 2015). Such oxidative stress can activate the p38 MAPK (mitogen-activated protein kinases). P38MAPK regulates numerous apoptotic and inflammatory pathways (Rashed et al., 2011).

Consistent with previous studies (Liu et al., 2016\& Kang et al., 2019), the kidneys of CP-injected rats exhibited an increase in apoptosis, as evidenced by reducing Bcl-2 levels and elevating Bax, P53, and caspase-3 levels. CP-mediated apoptosis is supposed to be produced by increased ROS generation, which in turn sparks the DNA damage, and ultimately lead to the initiation of the mitochondrial apoptotic pathway by enhancing the expression of pro-apoptotic proteins and down-regulating of anti-apoptotic proteins (Liu et al., 2016; ALHaithloul et al., 2019 \& Kang et al., 2019).

Numerous studies have suggested that using antioxidants may protect against CPinduced renal apoptosis (Liu et al., 2016, Rehman et al., 2012, El-Shabrawy et al., 2020). Herein, the GA-treated group showed significant downregulate $(\mathrm{p}<0.05)$ in the expression levels of pro-apoptotic caspase-3, P53, and Bax genes along with significant up-regulate $(\mathrm{p}<0.05)$ in the expression level of anti-apoptotic Bcl-2 gene, suggesting that GA might possess anti-apoptotic effects. Similar results were reported by Jin et al. (2017). 
These findings are consistent with those of Ahad et al. (2015), who discovered that GA significantly inhibited renal p38 MAPK and nuclear factor kappa B $(\mathrm{Nf}-\kappa \mathrm{B})$ activation while significantly lowering renal transforming growth factor-beta (TGF- $\beta$ ) and fibronectin levels. The use of GA resulted in a significant decrease in serum levels of pro-inflammatory cytokines like interleukin 1 beta (IL-1 $\beta$ ), IL-6, and tumor necrosis factor-alpha (TNF- $\alpha$ ).

In the current study, TNF- $\alpha$ gene expression levels increased significantly after CP injection. In the same manner, Said et al. (2015) stated that administration of CP significantly impaired oxidant/antioxidant balance and increased TNF- $\alpha$ level, with a significant impairment of kidney architecture and functions. TNF- $\alpha$ plays a key role in activating a large network of chemokines and cytokines, which mediates renal injury by inducing apoptosis (Yao et al., 2007; Sanz et al., 2008 \&Kotb et al., 2021).

TNF- $\alpha$ can cause tubular cell death and tissue damage directly through TNF receptor type 1 (TNFR1) and indirectly through TNF receptor type 2 (TNFR2). TNF- $\alpha$ is known to coordinate the activation of a large network of pro-inflammatory cytokines, including interleukin-4, 1, 6 (IL-4 $\beta$, IL-1, IL-6), monocyte chemotactic protein-1 (MCP1) and TGF- $\beta 1$ (Peres \&da Cunha, 2013). TNF- $\alpha$ has been shown to elicit a series of different inflammatory molecules that causes tissue damage, such as prostaglandins, IL-8 (interleukin-8), and ROS (Giebelen et al., 2007). The current study confirmed that GA reduced the elevated level of TNF- $\alpha$ after $\mathrm{CP}$ injection which indicates its protective effect against CP-induced nephrotoxicity. Similar results were stated before by Asci et al. (2017) and Bahrami et al. (2021).

The histopathological changes were consistent with the biochemical and molecular results that confirm the nephrotoxicity of $\mathrm{CP}$. The renal injury in the present study was associated with changes in the histoarchitecture of the kidney, loss of glomerular epithelium, dilation, edema, vascular congestion, and inflammatory cell infiltration. Prior studies revealed that the renal injury induced by CP is linked with the inflammation as it generates ROS that triggers the inflammatory mediators and causes a fast production of pro-inflammatory cytokines such as TNF- $\alpha$ as mentioned above, thus inducing necrosis (Bhat et al., 2018, ALHaithloul et al., 2019, Aladaileh et al., 2021).

Moreover, the loss of glomerular epithelium could be linked with lipid peroxidation that causes the alteration of the membrane permeability as a result of inactivating membrane-bound proteins, this will lead to loss of membrane integrity and cell death (Nirmala and Lopus, 2020 \&Aladaileh et al., 2021).

On the other hand, our study revealed the anti-inflammatory and antioxidant efficacy of GA in a dose-dependent manner. It plays a nephroprotective role by reserving and stabilizing the cell membranes integrity and renal architecture via scavenging activities of free radical (Reckziegel et al., 2016; Ghaznavi et al., 2018; Ahmadvand et al., 2020 \& Nouri et al., 2021)

Also, this study is strongly supported by the immunohistochemical expression of one of the most studied tight junction proteins, ZO-1. These proteins play an important role in maintaining the tight junction complex structure (Ahn et al., 2016) and signaling transduction (Murphy et al., 2013). In addition, they found on the intracellular surface of the plasma membrane, which provides a link between the integral membrane proteins and the actin component of the cytoskeleton, thus connecting the skeleton of the adjacent cells (Anderson and Van Itallie, 2009). The disruption in tight junction integrity may increase cell permeability, leading to protein and fluid leakage, thus causing renal damage as stated by Wichapoon et al., 2014.

In the present study, CP exhibited a loss of tight junction protein by decreasing the ZO-1 expression. This decrease may be due to the increase of oxidative stress that 
deactivates membrane-bound proteins, destroying the cell membrane (Smathers et al., 2011, Aladaileh et al., 2021). In line with this investigation, Yang et al. (2019) stated that ZO-1 was more sensitive to $\mathrm{H}_{2} \mathrm{O}_{2}$ and respond rapidly to oxidative stress. On the other hand, the administration of GA in a dose-dependent manner enhances the cellular integrity as demonstrated by increasing the expression of ZO-1 protein, this might be attributed to the antioxidative properties of GA That can scavenge ROS, strengthen the cellular antioxidant system, and restore the tight junction proteins. In the same manner, Cai et al. (2021) assumed that the pre-treatment with GA preserved the expression level of tight junction proteins ZO-1 in lipopolysaccharide (LPS-stimulated intestinal porcine enterocytes isolated from the jejunum (IPEC-J2) cells.

As a result, our findings highlight the protective roles of GA in mitigating tissue damage caused by oxidative stress via improving the levels of renal function markers, reducing the levels of urea, creatinine, and MDA, and increasing the levels of GSH and improving histopathological changes which may be associated with its antioxidant activities.

In conclusion, the current biochemical, molecular, histopathological, and immunohistochemical findings support Gallic acid's protective efficacy against CPinduced nephrotoxicity by enhancing the antioxidant defense mechanisms and by alleviating the inflammatory status. Due to the decrease of nephrotoxic side effects, GA administration may be beneficial for patients who have been using CP for a long time. Consequently, it could be combined with the pharmaceutical formulation of $\mathrm{CP}$ and may be used safely and effectively to treat cancer or autoimmune diseases. During CP therapy, cancer patients should consume more food sources that contain GA.

\section{Authors' Contributions:}

The authors participated equally in all parts of the research.

\section{Conflict of Interest:}

\section{Ethical Approval:}

The authors declare that they have no conflict of interest.

All applicable international, national, and institutional guidelines for the care and use of animals were followed. We respected the welfare of animals and excluded situations when animals were in pain.

\section{REFERENCES}

Abraham, P.; Indirani, K. and Sugumar, E. (2007) Effect of cyclophosphamide treatment on selected lysosomal enzymes in the kidney of rats. Experimental and Toxicologic Pathology, 59(2)143-9. doi: 10.1016/j.etp.2007.05.003.

Abraham, P.; Rabi, S. and Selvakumar, D. (2009) Protective effect of aminoguanidine against oxidative stress and bladder injury in cyclophosphamide-induced hemorrhagic cystitis in rat. Cell Biochemistry and Function, 27(1) 56-62. doi: 10.1002/cbf.1534.

Aebi, H. E. (1983) Catalase. In: Bergmeyer, HU (ed.). Methods of enzymatic analysis. Verlag Chemie, Weinhem, Germany, pp. 273-86.

Ahad, A.; Ahsan, H.; Mujeeb, M. and Siddiqui, W. A. (2015) Gallic acid ameliorates renal functions by inhibiting the activation of p38 MAPK in experimentally induced type 2 diabetic rats and cultured rat proximal tubular epithelial cells. Chemico-Biological Interactions, 5(240)292-303. doi: 10.1016/j.cbi.2015.08.026. 
Ahmadvand, H.; Nouryazdan, N.; Nasri, M. and Adibhesami, G. (2020) Renoprotective Effects of Gallic Acid Against Gentamicin Nephrotoxicity Through Amelioration of Oxidative Stress in Rats. Human and Animal Health, Brazilian Archives of Biology and Technology, 63. https://doi.org/10.1590/1678-4324-2020200131.

Ahmadvand, H.; Yalameha, B.; Adibhesami, G.; Nasri, M.; Naderi, N. and Babaeenezhad, E. (2019) The Protective Role of Gallic Acid Pretreatment on Renal Ischemia-reperfusion Injury in Rats. Reports of Biochemistry and Molecular Biology, 8(1) 42-8.

Akomolafe, S. F.; Akinyemi, A. J. and Anadozie, S. O. (2014) Phenolic Acids (Gallic and Tannic Acids) modulate antioxidant status and cisplatin induced nephrotoxicity in rats. International Scholarly Research Notices, 984709. doi: $10.1155 / 2014 / 984709$.

Aladaileh, S. H.; Al-Swailmi, F. K.; Abukhalil, M. H. and Mohammed H. Shalayel, M. H. (2021) Renoprotective Effect of Formononetin against CyclophosphamideInduced Oxidative Stress and Inflammation in Rat Kidney. Journal of Pharmaceutical Research International, 33(2)26-37. doi: 10.9734/jpri/2021/v33i231144.

Alfarouk, K. O.; Stock, C. M.; Taylor, S.; Walsh, M. and Muddathir, A. K.; Verduzco, D.; Bashir, A. H. H.; Mohammed, O. Y.; Elhassan, G. O.; Harguindey, S.; Reshkin, S. J.; Ibrahim, S. J. and Rauch, C. (2015) Resistance to cancer chemotherapy: failure in drug response from ADME to P-gp. Cancer Cell International, 15, 71. doi.org/10.1186/s12935-015-0221-1.

ALHaithloul, H. A.; Alotaibi, M. F.; Bin-Jumah, M.; Elgebaly, H. and Mahmoud, A. M. (2019) Olea europaea leaf extract up-regulates Nrf2/ ARE/HO-1 signaling and attenuates cyclophosphamide-induced oxidative stress, inflammation and apoptosis in rat kidney. Biomedicine \& Pharmacotherapy,111,67685.doi:10.1016/ j.biopha. 2018.12.112.

Al-Saeed, H. F.; Salah Eldin, G. M. M.; Ibrahim, S. E. and Kholoussy, A. B. (2017) Effect of Oxytocin on Cyclophosphamide- induced Nephrotoxicity in Male Albino Rats. Academy of Management Journal, 10,46(2)391-404 doi: 10.12816/0038262.

Amien, A. I.; Fahmy, S. R.; Abd-Elgleel, F. M. and Elaskalany, S. M. (2015) Renoprotective effect of Mangifera indica polysaccharides and silymarin against cyclophosphamide toxicity in rats. The Journal of Basic \& Applied Zoology,72,154-62. https://doi.org/10.1016/j.jobaz.2015.09.006.

Ahn, C.; Shin, D. H.; Lee, D.; Kang, S. M.; Seok, J. H.; Kang, H. Y. and Jeung, E. B. (2016) Expression of claudins, occludin, junction adhesion molecule A and zona occludens 1 in canine organs. Molecular Medicine Reports, 14(4)3697-703. https://doi.org/10.3892/mmr.2016.5725.

Anderson, J. M. and Van Itallie, C. M. (2009) Physiology and function of the tight junction. Cold Spring Harbor Perspectives in Biology, 1(2)a002584. doi: 10.1101/ cshperspect. a002584.

Asci, H.; Ozmen, O.; Ellidag, H. Y.; Aydin, B.; Bas, E. and Yilmaz, N. (2017) The impact of gallic acid on the methotrexate-induced kidney damage in rats. Journal of Food and Drug Analysis, 25(4)890-897. doi: 10.1016/j.jfda.2017.05.001.

Ayala, A.; Munoz, M. and Argüelles, S. (2014) Lipid Peroxidation: Production, Metabolism, and Signaling Mechanisms of Malondialdehyde and 4-Hydroxy-2Nonenal. Oxidative Medicine and Cellular Longevity, 360438- 469. doi: 10.1155/2014/360438.

Ayza, M.A.; Rajkapoor, B.; Wondafrash, D. Z. and Berhe, A. H. (2020) Protective Effect 
The Protective Effect of Gallic Acid on Cyclophosphamide-Induced Nephrotoxicity, Oxidative Stress, Genotoxicity, and Histopathological Alterations in Male Albino Rats.

of Croton macrostachyus (Euphorbiaceae) Stem Bark on CyclophosphamideInduced Nephrotoxicity in Rats. Journal of Experimental Pharmacology, 12, 275-83. doi.org/10.2147/JEP.S260731.

Baharmi, S. Kalantari, H.; Kalantar, M.; Goudarzi, M.; Mansouri, E. and Hadi. K. (2021) "Pretreatment with Gallic Acid Mitigates Cyclophosphamide Induced Inflammation and Oxidative Stress in Mice". Current Molecular Medicine, doi.org/10.2174/ 1874467214666210531162741.

Balagangadharan, K. (2012). Efficacy of Gallic acid on oxytetracycline induced nephrotoxicity in rats. International Journal of Pharma and Bio Sciences, 3: 492401

Barrera, G. (2012) Oxidative Stress and Lipid Peroxidation Products in Cancer Progression and Therapy. ISRN Oncology. 137289-310. doi: $10.5402 / 2012 / 137289$.

Bokolo, B and Adikwu, E. (2018) Protective assessment of cimetidine against cyclophosphamide-induced kidney injury. Asian Journal of Medical Science, 9(6)25-30. doi: 10.3126/ajms.v9i6.20669.

Boraschi, D. and Maurizi, G. (1998). Quantitation of dnafragmentation with diphenylamine. In apoptosis - Alaboratory manual of experimental methods. GCI publication; 153-161.

Borde, V.; Pangrikar, P. P. and Tekale, S. (2011) Gallic Acid in Ayurvedic Herbs and Formulations. Recent Research in Science and Technology, 3(7)51-4. https:// updatepublishing.com/journal/index.php/rrst/article/view/733.

Bhat, N.; Kalthur, S. G.; Padmashali, S. and Monappa, V. (2018) Toxic Effects of Different Doses of Cyclophosphamide on Liver and Kidney Tissue in Swiss Albino Mice: A Histopathological Study. Ethiopian-Journal of Health Sciences, 28 (6)711-716. doi: 10.4314/ejhs. v28i6.5.

Bustami, A.; Sopiah, P.; Muharam, R. and Wibowo, H. (2018) Effects of Gallic Acid and Its Derivates on Inflammatory Regulation of Endometriotic Primary Cultures: Study on NF-kB mRNA Expression and IL-6 Secretion. Biomedical and Pharmacology Journal, 11(3) 1479-84. https://dx.doi.org/10.13005/bpj/1514.

Cai, L.; Wei, Z.; Zhao, X.; Li, Y.; Li, X. and Jiang, X. (2021) Gallic acid mitigates LPSinduced inflammatory response via suppressing $\mathrm{NF}-\kappa \mathrm{B}$ signalling pathway in IPEC-J2 cells. Journal of Animal Physiology and Animal Nutrition, doi: 10.1111 /jpn. 13612.

Can Agca, A.; Batçığlu, K. and Şarer, E. (2020) Evaluation on Gallic Acid, EGCG Contents and Antiradical Activity of Green Tea and Black Tea Extracts. Journal of Faculty of Pharmacy of Ankara University, Ankara Eczacılık Fakültesi Dergisi, 44 (1) 50-60. doi: 10.33483/jfpau.644407.

Chashmi, N. A.; Emadi, S. and Khastar, H. (2017) Protective effects of hydroxytyrosol on gentamicin induced nephrotoxicity in mice. Biochemical and Biophysical Research Communications, 482(4)1427-9. doi: 10.1016/j.bbrc.2016.12.052.

Chilwant, K.S. and Muglikar, A.G. (2012). Effect of honey on gentamicin induced nephrotoxicity in albino rats. International Journal of Pharma and Bio Sciences, 3: $459-464$.

Culling, C.F.A. (2013) Handbook of Histopathological and Histochemical Techniques, Ed. 3, Butterworths, London, UK.

Dróżdż, P. and Pyrzynska, K. (2018) Assessment of polyphenol content and antioxidant activity of oak bark extracts. European Journal of Wood and Wood Products, 76,793-5 doi.org/10.1007/s00107-017-1280-x.

Ellman, G. L. (1959) Tissue sulfhydryl groups. Archives of Biochemistry and Biophysics, 
82(1)70 7. doi: 10.1016/0003-9861(59)90090-6.

El-Shabrawy, M.; Mishriki, A.; Attia, H.; Emad Aboulhoda, B.; Emam, M. and Wanas, H. (2020) Protective effect of tolvaptan against cyclophosphamide-induced nephrotoxicity in rat models. Pharmacology Research \& Perspectives, 8(5) e00659. doi: 10.1002/prp2.659.

Engwa, G. A. (2018) Free Radicals and the Role of Plant Phytochemicals as Antioxidants Against Oxidative Stress-Related Diseases, Phytochemicals-Source of Antioxidants and Role in Disease Prevention, Toshiki Asao and $\mathrm{Md}$ Asaduzzaman, Intech Open, doi: 10.5772/intechopen.76719.

Fereidoonfar, H.; Salehi-Arjmand, H.; Khadivi, A.; Akramian, M. and Safdari, L. (2019) Chemical variation and antioxidant capacity of sumac (Rhus coriaria L.). Industrial Crops and Products, 139,111518. doi.org/10.1016/j.indcrop. 2019. 111518.

Ghaznavi, H.; Fatemi, I.; Kalantari, H.; Hosseini Tabatabaei, S. M. T.; Mehrabani, M.; Gholamine, B.; Kalantar, M.; Mehrzadi, S. and Goudarzi, M. (2018) Ameliorative effects of gallic acid on gentamicin-induced nephrotoxicity in rats. Journal of Asian Natural Products Research, 20(12)1182-93. doi: 10. 1080/ 10286020.2017 .1384819$.

Giebelen, I. A.; van Westerloo, D. J.; LaRosa, G. J.; de Vos, A. F. and van der Poll, T. (2007) Local stimulation of alpha7 cholinergic receptors inhibits LPS-induced TNF-alpha release in the mouse lung. Shock, 28(6)700-3. doi: 10.1097/shk. 0b013e318054dd89.

Hamsa, T. and Kuttan, G. (2012) Tinospora cordifolia ameliorates urotoxic effect of cyclophosphamide by modulating GSH and cytokine levels. Experimental and Toxicologic Pathology, 64 (4)307-14. doi: 10.1016/j.etp.2010.09.003

Hedigan, K. (2010) Herbal medicine reduces chemotherapy toxicity. Nature Reviews Drug Discovery, 9,765. https://doi.org/10.1038/nrd3280.

Hornedo-Ortega, R.; González-Centeno, M. R.; Chira, K.; Jourdes, M. and Teissedre, P. (2020) Phenolic Compounds of Grapes and Wines: Key Compounds and Implications in Sensory Perception, Chemistry and Biochemistry of Winemaking, Wine Stabilization and Aging, Fernanda Cosme, Fernando M. Nunes and Luís Filipe-Ribeiro, IntechOpen, doi: 10.5772/intechopen.93127.

Jin, F.; Wan, C.; Li, W.; Yao, L.; Zhao, H.; Zou, Y.; Peng, D. and Huang, W. (2017) Formononetin protects against acetaminophen-induced hepatotoxicity through enhanced NRF2 activity. PloS one, 12(2)e0170900. doi: 10.1371/journal.pone. 0170900.

Kahkeshani, N.; Farzaei, F.; Fotouhi, M.; Alavi, S. S.; Bahramsoltani, R.; Naseri, R.; Momtaz, S.; Abbasabadi, Z.; Rahimi, R.; Farzaei, M. H. and Bishayee, A. (2019) Pharmacological effects of gallic acid in health and disease: A mechanistic review. Iranian Journal of Basic Medical Sciences, 22(3)225-37. doi: 10.22038 lijbms.2019.32806.7897.

Kang, X.; Jing, M.; Zhang, G.; He, L.; Hong, P. and Deng, C. (2019) The Ameliorating Effect of Plasma Protein From Tachypleus tridentatus on Cyclophosphamideinduced Acute Kidney Injury in Mice. Marine drugs, 17(4) 227. doi: 10. 3390/md17040227.

Khorsandi, K.; Kianmehr, Z.; Hosseinmardi, Z. and Hosseinzadeh, R. (2020) Anti-cancer effect of gallic acid in presence of lowlevel laser irradiation: ROS production and induction of apoptosis and ferroptosis. Cancer Cell International, 20, 18 https://doi.org/10.1186/s12935-020-1100-y.

Kilic, K.; Sakat, M.S.; Akdemir, F. N. E.; Yildirim, S.; Saglam, Y. S. and Askin, S. 
The Protective Effect of Gallic Acid on Cyclophosphamide-Induced Nephrotoxicity, Oxidative Stress, Genotoxicity, and Histopathological Alterations in Male Albino Rats.

(2019) Protective effect of gallic acid against cisplatin-induced ototoxicity in rats. Brazilian Journal of Otorhinolaryngology, 85, 267-74. doi: 10.1016/j.bjorl. 2018. 03.001.

Kotb, E. S.; Seraga, W. M.; Elshaarawy, R. F. M.; Hafez, H. S. and El-Khayat, Z. (2021) The protective role of Gallic acid in Cisplatin nephrotoxicity. Frontiers in Scientific Research and Technology Journal, 2(1)48-52. doi: 10.21608/fsrt. 2021. 77860.1040 .

Krishna, G.; Kropko, M. L. and Ciaravino, J. C. (1991) Simultaneous micronucleus and chromosome aberration assessment in the rat. Mutation Research Letters, 264(1), 29-35.

Kumari, S.; Panda, S.; Mangaraj, M.; Mandal, M. and Mahapatra, P. (2008) Plasma MDA and antioxidant vitamins in diabetic retinopathy. Indian Journal of Clinical Biochemistry, 23(2) 158-62. doi: 10.1007/s12291-008-0035-1.

Liu, Q.; Lin, X.; Li, H.; Yuan, J.; Peng, Y.; Dong, L. and Dai, S. (2016) Paeoniflorin ameliorates renal function in cyclophosphamide-induced mice via AMPK suppressed inflammation and apoptosis. Biomedicine \&. Pharmacotherapy, 84,1899-905. doi: 10.1016/j.biopha.2016.10.097.

Livak, K. J. and Schmittgen, T. D. (2001) Analysis of relative gene expression data using real-time quantitative PCR and the 2(-Delta Delta C(T)) Method. Methods, 25(4):402-8.

Locatelli, C.; Filippin-Monteiro, F. B.; Centa, A. and Creczinsky-Pasa, T. B. (2013) Handbook on Gallic Acid: Natural Occurrences, Antioxidant Properties and Health Implications (Biochemistry Research Trends), (4th Ed.). Nova Science Pub Inc. 1-23.

Manshare, K.; Anand, A.; Mahajan, S.; Satija, S.; Sharma, N.; Khurana, N.; Duggal, N. and Mehta, M. (2018) Evaluation of Nephroprotective Activity of Gallic Acid in Gentamicin-induced rat Model of Nephrotoxicity. International Journal of Green Pharmacy. Special Issue, 48-52. doihttp://dx.doi.org/10.22377/ijgp.v12i02.1829.

Matassov, D.; Kagan, T.; Leblanc, J.; Sikorska, M. and Zakeri, Z. (2004) Measurement of apoptosis by DNA fragmentation. Methods in molecular biology (Clifton, N.J.) 282:1-17 PMID: 15105553 doi: 10.1385/1-59259-812-9:001.

Murphy, A. M.; Krlin, R. M. and Goldman, H. B. (2013) Treatment of overactive bladder: what is on the horizon? International Urogynecology Journal, 1, 5-13. doi: 10.1007/s00192-012-1860-6.

Nabavi, S. M.; Habtemariam, S.; Nabavi, S. F.; Sureda, A.; Daglia, M.; Moghaddam, A. H. and Amani, M. A. (2013) Protective effect of gallic acid isolated from Peltiphyllum peltatum against sodium fluoride-induced oxidative stress in rat's kidney. Molecular and Cellular Biochemistry, 372(1-2) 233-9.doi: 10.1007 /s11010-012-1464-y.

Nagaraj, S.; Rajaram, M.; Arulmurugan, P.; Baskaraboopathy, A.; Karuppasamy, K.; Jayappriyan, K.; Sundararaj, R. and Rengasamy, R. (2012) Antiproliferative potential of astaxanthin-rich alga Haematococcus pluvialis Flotow on human hepatic cancer (HepG2) cell line. Biomedicine and Preventive Nutrition, 2(3)14953. https://doi.org/10.1016/j.bionut.2012.03.009.

Nirmala, J. G. and Lopus, M. (2020) Cell death mechanisms in eukaryotes. Cell Biology and Toxicology, 36(2) 145-64. doi: 10.1007/s10565-019-09496-2.

Nouri, A.; Heibati, F. and Heidarian, E. (2021) Gallic acid exerts anti-inflammatory, anti-oxidative stress, and nephroprotective effects against paraquat-induced renal injury in male rats. Naunyn-Schmiedeberg's Archives and Pharmacology, 394(1)1-9. doi: 10.1007/s00210-020-01931-0. 
Oboh, G.; Ogunsuyi, O. B.; Ogunbadejo, M. D. and Adefegha, S. A. (2016) Influence of gallic acid on $\alpha$-amylase and $\alpha$-glucosidase inhibitory properties of acarbose. Journal of Food Drug Analysis, 24 (3) 627-34. doi: 10.1016/j.jfda.2016.03.003.

Ohkawa, H.; Ohishi, N. and Yagi, K. (1979) Assay for lipid peroxides in animal tissues by thiobarbituric acid reaction. Analytical Biochemistry, 95, 351-58. doi.org/10.1016/0003-2697(79)90738-3.

Ola Davies, E. O.; Olukole, S. G. and Lanipekun, D. O. (2018) Gallic Acid Ameliorates Bisphenol A-Induced Toxicity in Wistar Rats. Iranian of Journal of Toxicology, 12(4)11-18. https://www.sid.ir/en/journal/ViewPaper.aspx?id=719517.

Olayinka, E. T.; Ore, A.; Adeyemo, O. A. and Ola, O. S. (2016) Ameliorative Effect of Gallic Acid on Methotrexate-Induced Hepatotoxicity and Nephrotoxicity in Rat. Journal of Xenobiotics, 6 (1) 6092. doi: 10.4081/xeno.2016.6092.

Olayinka, E. T.; Ore, A.; Ola, O. S. and Adeyemo, O. (2015) Ameliorative effect of gallic acid on cyclophosphamide-induced oxidative injury and hepatic dysfunction in rats. Medical Sciences (Basil), 3(3)78-92. doi: 10.3390/ medsci3030078

Osawa, T.; Davies, D. and Hartley, J. A. (2011) Mechanism of cell death resulting from DNA interstrand cross-linking in mammalian cells. Cell Death and Disease, 2(8) e187. doi: 10.1038/cddis.2011.70.

Pedeson, M. A.; Scott, C. S. and William, A. B. (1990) Evaluation of lipid peroxidation in inflammatory patients. Annals of the New York Academy of Sciences, 559, 45.

Peres, L. A. B. and da Cunha, A. D. Jr. (2013) Acute nephrotoxicity of cisplatin: Molecular mechanisms. Brazilian Journal of Nephrology, 35(4)332-40. doi: 10.5935/0101-2800.20130052.

Rajamanickam, K.; Yang, J. and Sakharkar, M. K. (2019) Gallic Acid Potentiates the Antimicrobial Activity of Tulathromycin Against Two Key Bovine Respiratory Disease (BRD) Causing-Pathogens. Frontiers in Pharmacology, 9,1486. doi: 10.3389/fphar.2018.01486.

Rao, A. S.; Reddy, S. G.; Babu, P. P. and Reddy, A. R. (2010) The antioxidant and antiproliferative activities of methanolic extracts from Njavara rice bran. BMC Complementary Medicine and Therapies, 10,4. doi: 10.1186/1472-6882-10-4.

Rashed, L.; Hashem, R. and Soliman, H. (2011) Oxytocin inhibits NADPH oxidase and P38 MAPK in cisplatin-induced nephrotoxicity. Biomedicine and Pharmacotherapy, 65,474-80. doi: 10.1016/j.biopha.2011.07.001.

Reckziegel, P.; Dias, V. T.; Benvegnú, D. M.; Boufleur, N.; Barcelos, R. C. S.; Segat, H. J.; Pase, C. S.; Dos Santos, C. M. M.; Flores, É. M. M. and Bürger, M. E. (2016) Antioxidant protection of gallic acid against toxicity induced by $\mathrm{Pb}$ in blood, liver and kidney of rats. Toxicology Reports, 3,351-56. doi: 10.1016/j.toxrep. 2016.02.005.

Rehman, M. U.; Tahir, M.; Ali, F.; Qamar, W.; Lateef, A.; Khan, R.; Quaiyoom, A.; Hamiza, O. and Sultana, S. (2012) Cyclophosphamide induced nephrotoxicity, genotoxicity, and damage in kidney genomic DNA of Swiss albino mice: the protective effect of Ellagic acid. Molecular and Cellular Biochemistry, 365(1-2) 119-27. doi: 10.1007/s11010-012-1250-x.

Rueff, J. and Rodrigues, A. S. (2016) Cancer drug resistance: a brief overview from a genetic viewpoint. Methods in Molecular Biology, 1395,1-18. doi: 10.1007/9781-4939-3347-1_1.

Said, M. M. (2011) The protective effect of eugenol against gentamicin-induced nephrotoxicity and oxidative damage in rat kidney. Fundamental and Clinical pharmacology, 25(6)708-16. doi: 10.1111/j.1472-8206.2010.00900.x. 
The Protective Effect of Gallic Acid on Cyclophosphamide-Induced Nephrotoxicity, Oxidative Stress, Genotoxicity, and Histopathological Alterations in Male Albino Rats.

Said, E.; Elkashef, W. F. and Abdelaziz, R. R. (2015) Tranilast ameliorates cyclophosphamide-induced lung injury and nephrotoxicity. Canadian Journal of Physiology and Pharmacology, 94 (4)347-58. doi: 10.1139/cjpp-2015-0070.

Safaei, F.; Mehrzadi, S.; KhademHaghighian, H.; Hosseinzadeh, A.; Nesari, A.; Dolatshahi, M.; Esmaeilizadeh, M. and Goudarzi, M. (2018) Protective effects of gallic acid against methotrexate induced toxicity in rats. Acta Chirurgica Belgica, 118 (3)152-160. doi: 10.1080/00015458.2017.1394672.

Sanz, A.; Santamari’a, B.; Ruiz-Ortega, M.; Egido, J. and Ortiz, A. (2008) Mechanisms of renal apoptosis in health and disease. Journal of American Society of Nephrology, 19(9)1634-42. doi: 10.1681/ASN.2007121336.

Smathers, R. L.; Galligan, J. J.; Stewart, B. J. and Petersen, D. R. (2011) Overview of lipid peroxidation products and hepatic protein modification in alcoholic liver disease. Chemico-Biological Interaction, 192(1-2)107-12. doi: 10.1016/j.cbi. 2011.02.021.

Todd, J.C.; Sanford, A. H.; Davidson, I. and Henry, J. B. (1974) Clinical diagnosis and management by laboratory methods. 15th edition, pbl. W.B. Saunders and Co., Philadelphia, pp. 552-87.

Tripathi, D. and Jena, G. (2009): Intervention of astaxanthin against cyclophosphamide induced oxidative stress and DNA damage: a study in mice. Chemico-Biological Interaction, 180 (3) 398-406. doi: 10.1016/j.cbi.2009.03.017.

Trujillo-Correa, A. I.; Quintero-Gil, D. C. and Diaz-Castillo, F.; Quiñones, W.; Robledo, S. M. and Martinez-Gutierrez, M. (2019) In vitro and in silico anti-dengue activity of compounds obtained from Psidium guajava through bioprospecting. BMC Complementary and Alternative Medicine, 19(1)298. https://doi.org/ 10.1186/s12906-019-2695-1.

Variya, B. C.; Bakrania, A. K. and Patel, S. S. (2020) Antidiabetic potential of gallic acid from Emblica officinalis: Improved glucose transporters and insulin sensitivity through PPAR- $\gamma$ and Akt signaling. Phytomedicine,73, 152906. doi: 10.1016/j.phymed.2019.152906.

Wang, H.; Provan, G. J. and Helliwell, K. (2003) Determination of hamamelitannin, catechins and gallic acid in witch hazel bark, twig and leaf by HPLC. Journal of Pharmaceutical and Biomedical Analysis, 33(4)539-44. doi: 10.1016/s0731 7085(03)00303-0.

Wichapoon, B.; Punsawad, C.; Chaisri, U. and Viriyavejaku, P. (2014) Glomerular changes and alterations of zonula occludens- 1 in the kidneys of Plasmodium falciparum malaria patients. Malaria Journal, 13,176. https://doi.org/10.1186 /1475-2875-13-176.

Yang, R.; Hui, Q.; Jiang, Q.; Liu, S.; Zhang, H.; Wu, J.; Lin, F.; Karmin, O. and Yang, C. (2019) Effect of Manitoba-Grown Red-Osier Dogwood Extracts on Recovering Caco-2 Cells from H2O2-Induced Oxidative Damage. Antioxidants (Basel), 8 (8)250. doi: 10.3390/antiox8080250.

Yao, X.; Panichpisal, K.; Kurtzman, N. and Nugent, K. (2007) Cisplatin Nephrotoxicity: A Review. The American Journal of The Medical Science, 334 (2)115-24. doi: 10.1097/MAJ.0b013e31812dfe1e.

Yurdakul, T.; Kulaksizoglu, H.; Pişkin, M.M.; Avunduk, M.C.; Ertemli, E.; Gokçe, G.;Bariskander, H.; Byükbaş, S. and Kocabas, V. (2010) Combination antioxidant effect of $\alpha$-tocoferol and erdosteine in ischemia reperfusion injury in rat model. International Urology and Nephrology, 42(3)647-55. doi: 10.1007/s11255-009-9641-y.

Zhang, T.; Ma, L.; Wu, P.; Li, W.; Li, T.; Gu, R.; Dan, X.; Li, Z.; Fan, X. and Xiao, Z. 
(2019) Gallic acid has anticancer activity and enhances the anticancer effects of cisplatin in non-small cell lung cancer A549 cells via the JAK/STAT3 signaling pathway. Oncology Reports, 41(3)1779-88. doi: 10.3892/or.2019.6976.

\section{ARABIC SUMMARY}

التأثير الوقائي لحض الجاليك ضد السمية الكلوية ، والإجهاد التأكسدي ، والسمية الوراثية ، والتغيرات النسيجية

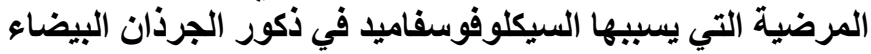

$$
\text { شيرين حسن بدوي الوكيل و أمينة عبد المنعم شحاته عبد الرحمن }
$$

قسم علم الحيوان ـ كلية البنات للعلوم والآداب والتربية ـ جامعة عين شمس ـ شارع أسماء فهمى ـهليوبوليس-

$$
\text { القاهرة- مصر بامعة عير }
$$

يعتبر السيكلوفوسفاميد علاج كيميائي يستخدم لعلاج أنواع مختلفة من السرطان. و على الرغم من آثاره

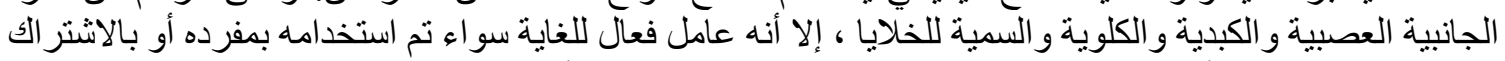

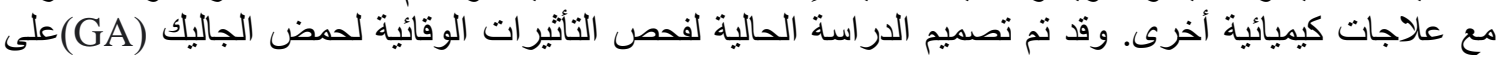

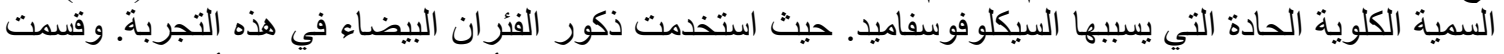

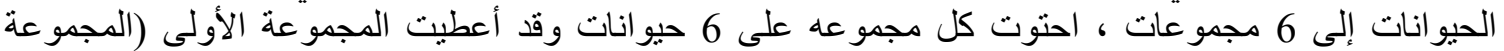

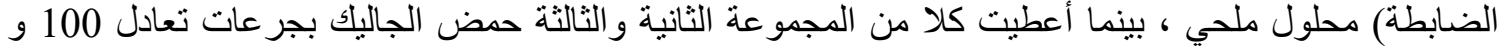

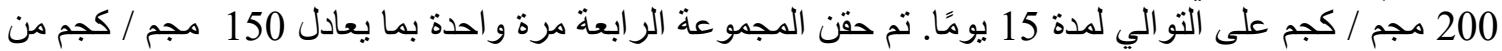

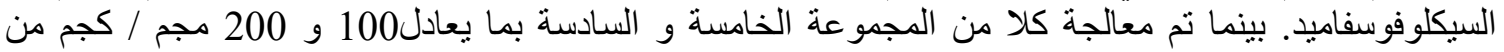

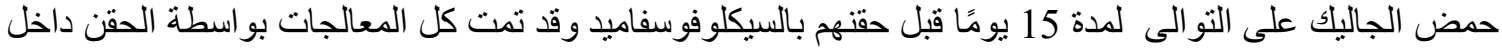

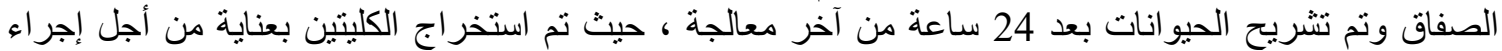

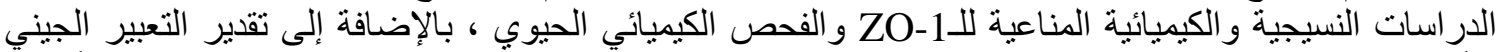

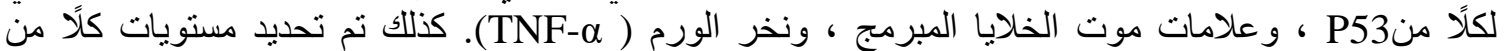

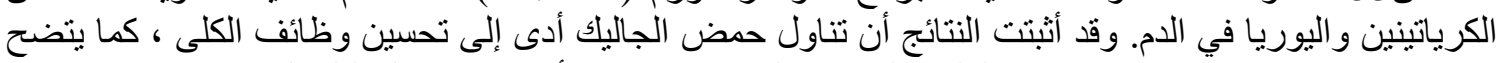

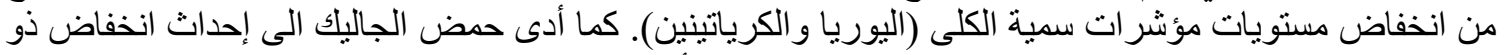

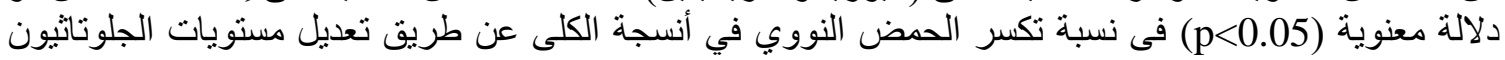

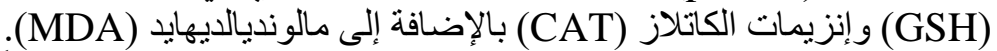

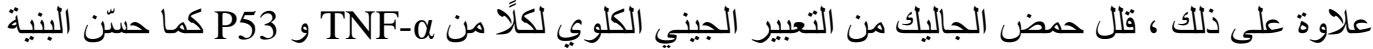

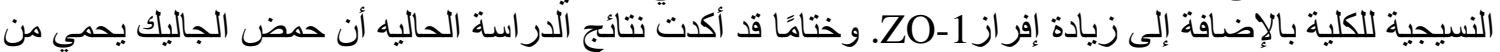

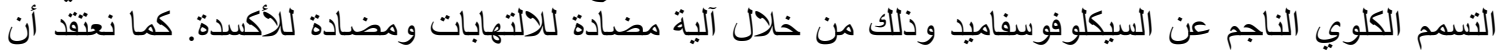
حمض الجاليك قد يكون له تأثير وقائي ضد السمية الكلوية التي يسبيها السيكلوفوسفاميد. 